\section{A REVIEW ON AUGMENTED REALITY TRACKING METHODS FOR MAINTENANCE OF ROBOTS}

\author{
Ye Sheng Koha*, Kai Woon Goha, Marvin Daresa, Che Fai Yeonga, \\ Eileen Su Lee Minga, Mohd. Shahrizal Sunarb,c, Yik Shin Teyd
}

aSchool of Electrical Engineering, Faculty of Engineering, Universiti Teknologi Malaysia, 81310, UTM Johor Bahru, Johor, Malaysia bMedia and Game Innovation Centre of Excellence, Institute of Human Centered Engineering, Universiti Teknologi Malaysia, 81310 UTM Johor Bahru, Johor, Malaysia cSchool of Computing, Faculty of Engineering, Universiti Teknologi Malaysia, 81310 UTM Johor Bahru, Johor, Malaysia dDF Automation and Robotics San. Bhd., 81310, Johor Bahru, Johor, Malaysia
Article history

Received

21 April 2020

Received in revised form

25 October 2020

Accepted

4 November 2020

Published online

17 December 2020

*Corresponding author yskoh@graudate.utm.my

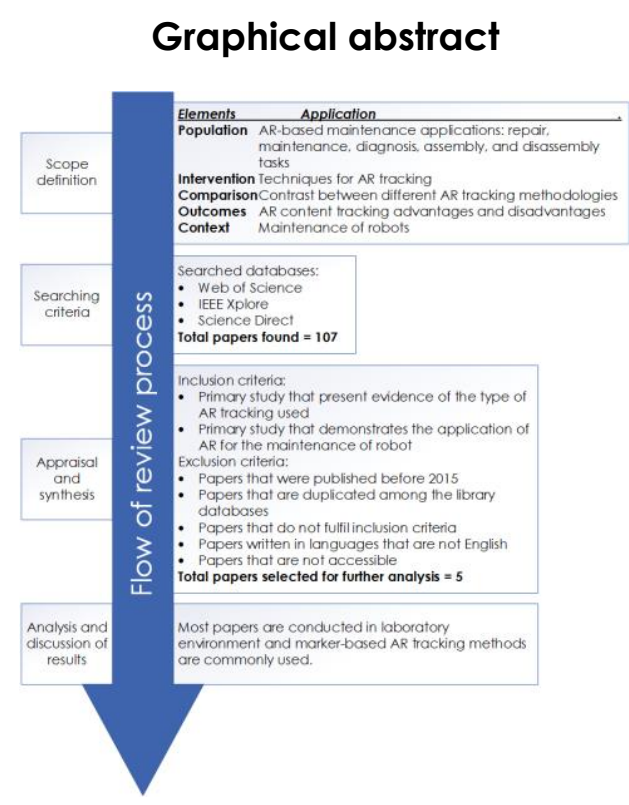

\begin{abstract}
Augmented reality (AR) in maintenance is a broad subject with many nuances when it comes to their implementation. The applications of these systems range from maintenance of large-scale assets such as buildings to smaller scale assets such as robots. Applications of AR in maintenance typically serves as a visual guide to assist users in diagnosis or steps needed to be performed for maintenance. In this paper, the tracking methods utilized in AR-based maintenance for robots are qualitatively evaluated. The reviewed works in this paper are between the years of 2015 to 2020 to ensure that the AR tracking methods are relatively state of the art. It is found that applications of AR-based maintenance for robots are uncommon in the scope defined in this research especially in the industrial environment as most reviewed works are conducted in a laboratory setting. In addition to that, it is found that marker-based tracking methods are commonly utilized in these applications.
\end{abstract}

Keywords: Augmented reality, AR, maintenance, robot, tracking

\begin{abstract}
Abstrak
Penggunaan realiti terimbuh (AR) dalam penyelenggaraan adalah suatu subjek di mana cara pelaksanaannya adalah berbagai-bagai. Aplikasi sistem AR boleh merangkumi penyelenggaraan aset berskala besar seperti bangunan sehinggalah aset berskala kecil seperti robot. Lazimnya, aplikasi AR dalam penyelenggaraan berfungsi sebagai panduan dalam bentuk visual untuk membantu pengguna melaksanakan aktiviti diagnostik ataupun memberi panduan untuk langkah-langkah aktiviti penyelenggaraan. Dalam kertas kajian ini, cara penjejakan yang digunakan dalam penyelenggaraan berunsur AR untuk robot dinilai secara kualitatif. Hanya kertas kajian terbitan antara tahun 2015 hingga 2020 dipilih untuk kajian ini bagi memastikan kaedah penjejakan AR dalam kertas kajian yang dipilih adalah secara relatifnya kaedah terkini. la didapati bahawa aplikasi penyelenggaraan berunsur AR untuk robot adalah jarang dalam skop kajian ini terutamanya dalam persekitaran industri kerana kebanyakkan kajian dilaksanakan dalam persekitaran makmal. Tambahan itu, ia juga didapati bahawa kaedah penjejakan berbentuk penanda adalah kaedah yang biasa diggunakan dalam aplikasi tersebut.

Kata kunci: Realiti terimbuh, AR, penyelenggaraan, robot, penjejakan

(c) 2021 Penerbit UTM Press. All rights reserved
\end{abstract}




\subsection{INTRODUCTION}

Amin and Govilkar [1] defines AR as the merging of real world environment with information coming from digital processing in real-time. Mekni and Lemieux [2] describes it as the real-time mixing of virtual content with the real world environment. Schmalstieg and Höllerer [3] describes AR as the overlaying of computer-generated information on the real world that helps to amplify human perception and cognition. From the definitions, AR can be inferred as a real-time layering of virtual objects on top of the physical environment. In AR systems, tracking dictates the spatial location of the virtual object in the physical environment. To achieve this, the positions and orientations of the tracked objects are constantly updated and fed to the system [3].

A basic AR system requires at least three components which are tracking, registration, and visualization [3]. The tracking component refers to a continuous measurement of a tracked real object's position and orientation relative to the AR display [3]. The tracking of the real object is also conducted in three-dimensional (position) or six-dimensional (position and orientation) so that the system knows where to display the virtual object relative to the AR display [3]. The registration component is a process that maps the virtual object onto the spatial location of the real object and visualization refers to the positioning of the virtual object in the physical scene in such a way that it can be easily understood.

Generally, there are three types of tracking in AR systems which are visual-based, sensor-based, and hybrid which combines both visual and sensor [4]. Visual-based tracking uses information from reference images or CAD models of tracked objects and is categorised into model, feature, or marker based [3], [4] while sensor-based methods uses sensors such as WiFi, GPS, and IMU to determine either position or orientation [3]. On the other hand, hybrid systems combines the spatial information from sensors and cameras to complement their respective limitations [3], [4]. A limitation of cameras is the limited field of view (FOV). Visual tracking requires the tracked object to be always within the camera's FOV, but this is not always possible especially during maintenance. Another limitation is occlusion, where the tracked object is behind another physical object thus blocking it from the camera's view. Both limitations can be overcome by using sensors which will determine the user's position relative to the physical environment. However, sensors require calibration and will drift over time. Although hybrid systems are theoretically more accurate and robust than their individual counterparts, it is the least used in maintenance applications when compared to visual-based methods [4]. This is likely due to the complexity of hybrid systems which requires the AR system to integrate information from both sides in addition to calibration of sensors which increases computational cost whereas visual-based solutions can achieve tracking with only information from reference images or CAD models.

There are a wide range of applications for $A R$ technology such as education and training, maintenance tasks, construction, and medical applications. For example, Rongting et al. [5] researched on several AR products that were used to teach science subjects while Detmer et al. [6] reviewed systems that uses AR to train users in medical treatment of renal stones. AR is also used to teach English to non-native speakers [7] and used as a colouring platform for preschool education [8]. In maintenance, Alrashed et al. [9] proposed mobile AR for remote maintenance of aerospace engines while Luxenburger et al. [10] proposed robot-human collaboration assembly in aircraft with AR elements. Flatt et al. [1 1 ] presented an AR application to be used in a production plant to assist in maintenance by providing information such as plant process data and digital sticky notes. AR is also used for teleoperated maintenance or assembly where better visualization of the environment can be achieved [12]. In construction, Sreeram et al. [13] proposed an AR solution in drones to visualize building construction phases before the construction occurs as a virtual tour. AR technologies see more widespread use in supporting users on visualization of information in both 2D and 3D. Some applications are also not restricted to standalone AR implementations such as a virtual assembly tasks by Zaldívar-Colado et al. [14] which used $A R$ in conjunction with virtual reality (mixed reality).

On the aspect of maintenance, there have been several reviews conducted that provides an overview on the state of AR for maintenance. For instance, Fernández del Amo et al. [15] conducted a systematic review on content-related techniques used for knowledge transfer in the field of maintenance. The maintenance criteria defined in the paper are assembly, design, diagnosis, management, repair, and training on medium to long life complex assets regardless of industry. Similarly, Palmarini et al. [4] conducted a systematic review on advantages and disadvantages of AR in industrial maintenance. The maintenance criteria selected in the paper are assembly, repair, diagnosis, and training but no specifications on the type of assets or industry. Both reviews are useful to look at the maintenance applications of AR in a high-level overview.

On the other hand, Coleta et al. [16] conducted a study on the usage of AR-based maintenance in aiding telecommunications industry. Fraga-Lamas et al. [17] also conducted an industry specific review on AR applications in shipbuilding which also covers maintenance among other applications. However, there is little relevant work done on the applications of AR for the maintenance of robots. These researches are typically conducted in a controlled laboratory environment rather than a production environment [18]. This review paper will focus on AR tracking techniques used in maintenance of robots. 


\subsection{METHODOLOGY}

The objective of this research is to review existing solutions implemented for maintenance of robots. The method used to conduct this review was inspired by similar reviews in this field [4], [15]. These papers conducted a Systematic Literature Review (SLR) which is defined by Booth et al. [19] as a "systematic, explicit, and reproducible method for identifying, evaluating, and synthesising the existing body of completed and recorded work made by researchers, scholars, and practitioners."

Booth et al. [19] proposed a SALSA framework which is a SLR methodology to structure a review. A breakdown of the SLR methodology adopted for this paper as shown in Figure 1.

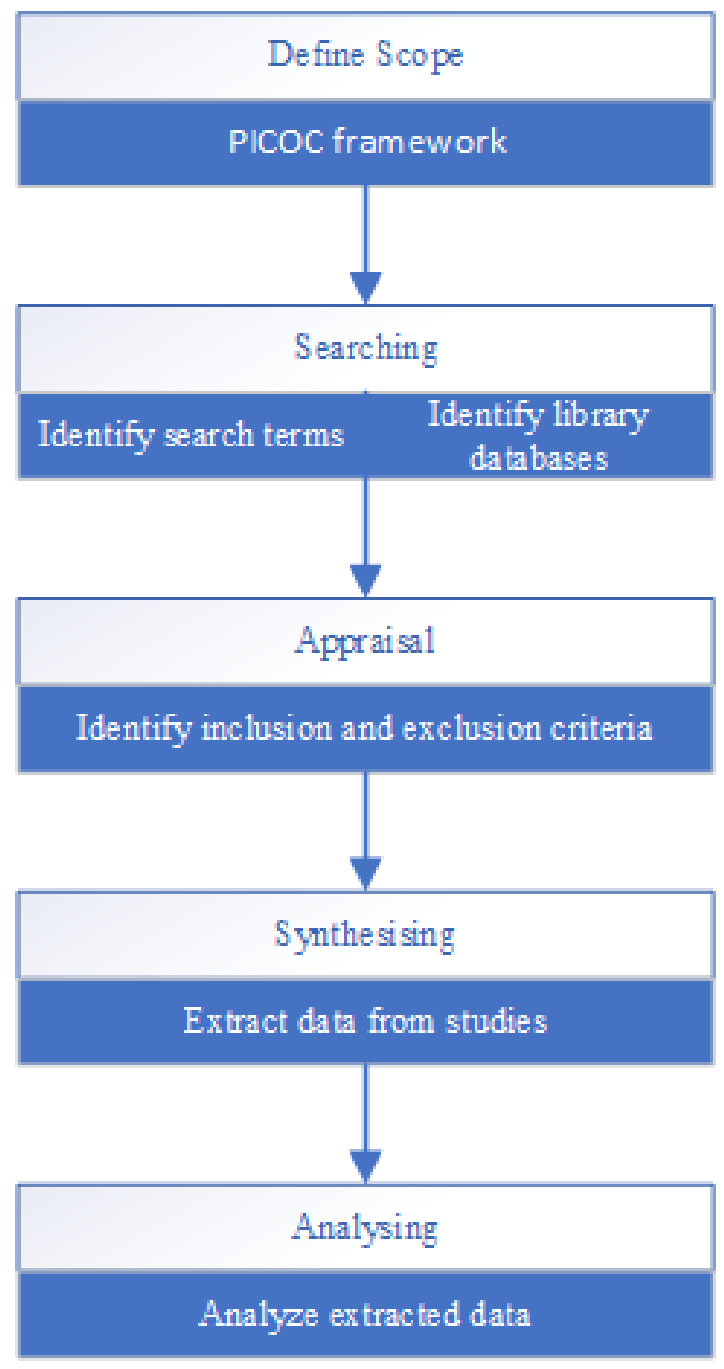

Figure 1 SLR methodology adopted which consists of five steps (above) and its outcomes (below)

\section{Step 1 - Define Scope}

In this step, the research topic is structured into answerable research questions that sets the objectives and outcomes of the research. To define the scope pertaining to the research, PICOC (Population, Intervention, Comparison, Outcome, and Context) framework is used. The elements of PICOC are explained as shown in Table 1.

Table 1 Elements of PICOC in SLR methodology [19]

\begin{tabular}{|c|c|}
\hline Elements & Application \\
\hline Population & $\begin{array}{l}\text { The problem that the research is trying to } \\
\text { answer. }\end{array}$ \\
\hline Intervention & $\begin{array}{l}\text { List of available methods used to solve } \\
\text { the problem. }\end{array}$ \\
\hline Comparison & $\begin{array}{l}\text { Alternatives to available methods or } \\
\text { contrast between available methods. }\end{array}$ \\
\hline Outcomes & $\begin{array}{l}\text { Parameters used to measure the impacts } \\
\text { of the methods. }\end{array}$ \\
\hline Context & $\begin{array}{l}\text { The specification of the population in } \\
\text { terms of settings, areas, or countries. }\end{array}$ \\
\hline
\end{tabular}

Using PICOC framework, the research topic is structured as shown in Table 2.

Table 2 SLR research scope in this paper defined by PICOC framework

\begin{tabular}{ll}
\hline Elements & Application \\
\hline Population & $\begin{array}{l}\text { AR-based maintenance applications: } \\
\text { repair, maintenance, diagnosis, assembly, } \\
\text { and disassembly tasks }\end{array}$ \\
\hline Intervention & Techniques for AR tracking \\
\hline Comparison & $\begin{array}{l}\text { Contrast between different AR tracking } \\
\text { methodologies }\end{array}$ \\
\hline Outcomes & $\begin{array}{l}\text { AR content tracking advantages and } \\
\text { disadvantages }\end{array}$ \\
\hline Context & Maintenance of robots \\
\hline
\end{tabular}

\section{Step 2 - Searching}

In this step, it consists of the identification of search terms used that are relevant to the research. The list of library databases to be used to search for the relevant works is also determined. The search terms utilised is ("AR" OR augmented reality) AND (robot) AND (maintenance OR repair OR assembly OR disassembly OR diagnosis).

The library databases chosen to search for relevant works are:
i. Web of Science
ii. IEEE Xplore
iii.Science Direct

These three libraries were selected as they cover many engineering related journals and research papers. The reviewed papers are selected from publications between the year of 2015 to 2020 to ensure that the reviewed publications are relatively state-of-the-art. The results of the search are as tabulated in Table 3 below. 
Table 3 Search fields used for the libraries and their returned results

\begin{tabular}{llrl}
\hline Database & Search Fields & $\begin{array}{l}\text { Returned } \\
\text { number } \\
\text { results }\end{array}$ \\
\hline IEEE Xplore & All metadata & 30 \\
\hline $\begin{array}{l}\text { Web of } \\
\text { Science }\end{array}$ & $\begin{array}{l}\text { Title, Abstract, Author } \\
\text { Keywords, } \\
\text { Keywords Plus }\end{array}$ & 70 \\
\hline $\begin{array}{l}\text { Science } \\
\text { Direct }\end{array}$ & $\begin{array}{l}\text { Title, Abstract, Author } \\
\text { Keywords }\end{array}$ & 25 \\
\hline Total & & 125 \\
\hline
\end{tabular}

\section{Step 3 - Appraisal}

For this step, the inclusion and exclusion criteria are utilized as an initial screening of the available research work.

Inclusion criteria:

i. Primary study that present evidence of the type of AR tracking used

ii. Primary study that demonstrates the application of AR for the maintenance of robot

Exclusion criteria:

i. Papers that were published before 2015

ii. Papers that are duplicated among the library databases

iii. Papers that do not fulfil inclusion criteria

iv. Papers written in languages that are not English

v. Papers that are not accessible

Step 4 - Synthesising

In the synthesising step, information from the selected papers are extracted and classified. For a qualitative analysis, it is proposed by Booth et al. [19] that thematic synthesis is a suitable for this step. The themes identified for the selected papers are as shown in Table 4 below.

Table 4 Data extraction example from two papers

\begin{tabular}{lll}
\hline Theme & Paper 1 & Paper 2 \\
\hline Asset & Switch cabinet & Robotic arm \\
\hline Task & Repair guidance & Diagnosis \\
\hline Platform & $\begin{array}{l}\text { HMD, projector, } \\
\text { tablet PC }\end{array}$ & HMD \\
\hline $\begin{array}{l}\text { Tracking } \\
\text { technique }\end{array}$ & Marker-based & Marker-based \\
\hline
\end{tabular}

Step 5 - Analysing

The analysis step evaluates the synthesised data from previous step. In this step, the qualitative results from the synthesis step is used to correlate with the research question of this paper. First, an individual analysis of the platform and tracking methods employed. Then, the systems developed are contrasted with each other before a conclusion is drawn from the results of the contrast.

\subsection{RESULTS AND DISCUSSION}

Aschenbrenner et al. [20] conducted a study on the repair of a controller inside Robotstar $\vee$ switch cabinet manufactured by KUKA Industries. In their study, three out of the four methods employed to perform the maintenance operation are AR-based. The differences between these three methods are the platform in which they are deployed on which are HMD (Epson Moverio BT200), projector (Panasonic PTVZ575N), and tablet PC (ASUS MEMO ME302C Tablet). All three methods employ the same tracking technique which is marker-based.

Avalle et al. [21] proposed a fault visualization on a robotic arm using a HMD (Hololens) as part of humanrobot collaboration (HRC) systems related to safety. The tracking method used is marker-based to display the virtual robotic arm. It is also supported by an image segmentation method that utilizes a server to visualize the robot from the same point of view (POV) of the user and calculate the pose of icons to display the different fault icons on the joints of the robotic arm. This ensures the icon is always visible to the user's POV. In other HRC related studies, Hietanen et al. [22] proposed using AR in HRC workspaces that shows robot status for safety purposes using projector or HMD (Hololens) with marker-based tracking. Similarly, Michalos et al. [23], [24] and Makris et al. [25] used AR in HRC systems to display robot trajectory through a HMD via marker-based tracking. Other HRC systems such as those proposed by

Kousi et al. [26] developed a human-robot interaction (HRI) system that allows user to directly control, program, and communicate with mobile robots via an AR interface. The system uses a HMD and marker-based tracking to display the user interface (UI) for the user. Although this system is not directly related to the maintenance of a robot, the system can be used to diagnose a robot as it shows real-time information of the robot and is thus included in the review. In another similar study, Guhl et al. [27], [28] developed a HRI system that utilizes AR for simulation of pick-and-place motions of the robotic arm for collision detection. The system is compatible with HMD (Hololens), tablet PCs (Android and Windows), and also laptops and uses marker-based tracking. In a different study, Andersson et al. [18] proposed a system that visualizes robot joint states and trajectory in AR via HMD (PENNY), tablets (Windows, iOS, and Android), and also PC and markerless-based tracking was performed using keypoints estimation. Similarly, other $\mathrm{HRI}$ research related to programming of industrial robots via AR have been conducted [29][32] but these researches are excluded as they do not indicate robot features that such as robot trajectories that may be used for diagnosis purposes. 
Mourtzis et al. [33] developed a maintenance guide to perform battery pack replacements for an industrial robot. The solution involves the usage of marker-based AR tracking on a HMD (Vuzix Star 1200XL). However, the solution also requires a laptop PC to execute the AR application and mobile device to interact with the AR application menu.

De Pace et al. [34] proposed a system to assist in an assembly task of a $3 \mathrm{D}$ printed simplified end effector to an industrial robot. The tracking method used is also marker based and is deployed on a HMD (Microsoft Hololens). Similarly, Alves et al. [35] developed a system on a tablet PC and projector that guides the user in an assembly task. However, this research was not included in the results as the application was on Lego blocks and not a robot.

Table 5 Contrast of advantages and disadvantages of tracking method in each system

\begin{tabular}{|c|c|c|}
\hline Author & Advantages & Disadvantages \\
\hline Aschenbrenner et al. & $\begin{array}{l}\text { Compatible with multiple platforms } \\
\text { Tracking is marker-based only and easier to } \\
\text { implement }\end{array}$ & $\begin{array}{l}\text { Cannot replicate occlusion } \\
\text { Requires interaction from end user for marker setup and } \\
\text { maintenance }\end{array}$ \\
\hline Avalle et al. & $\begin{array}{l}\text { Able to replicate occlusion } \\
\text { Adaptively displays fault icons relative to user's } \\
\text { POV }\end{array}$ & $\begin{array}{l}\text { Computationally expensive thus requiring a server } \\
\text { Requires interaction from end user for marker setup and } \\
\text { maintenance }\end{array}$ \\
\hline Hietanen et al. & $\begin{array}{l}\text { Compatible with multiple platforms } \\
\text { Tracking is marker-based only and easier to } \\
\text { implement }\end{array}$ & $\begin{array}{l}\text { Cannot replicate occlusion } \\
\text { Requires interaction from end user for marker setup and } \\
\text { maintenance }\end{array}$ \\
\hline Michalos et al. & $\begin{array}{l}\text { Tracking is marker-based only and easier to } \\
\text { implement }\end{array}$ & $\begin{array}{l}\text { Cannot replicate occlusion } \\
\text { Requires interaction from end user for marker setup and } \\
\text { maintenance }\end{array}$ \\
\hline Makris et al. & $\begin{array}{l}\text { Tracking is marker-based only and easier to } \\
\text { implement }\end{array}$ & $\begin{array}{l}\text { Cannot replicate occlusion } \\
\text { Requires interaction from end user for marker setup and } \\
\text { maintenance }\end{array}$ \\
\hline Kousi et al. & $\begin{array}{l}\text { Tracking is marker-based only and easier to } \\
\text { implement }\end{array}$ & $\begin{array}{l}\text { Cannot replicate occlusion } \\
\text { Requires interaction from end user for marker setup and } \\
\text { maintenance }\end{array}$ \\
\hline Guhl et al. & $\begin{array}{l}\text { Compatible with multiple platforms } \\
\text { Tracking is marker-based only and easier to } \\
\text { implement }\end{array}$ & $\begin{array}{l}\text { Cannot replicate occlusion } \\
\text { Requires interaction from end user for marker setup and } \\
\text { maintenance }\end{array}$ \\
\hline Andersson et al. & $\begin{array}{l}\text { Compatible with multiple platforms } \\
\text { Tracking is keypoints-based which is markerless }\end{array}$ & $\begin{array}{l}\text { Cannot replicate occlusion } \\
\text { Keypoint-based methods are susceptible to reflective } \\
\text { surfaces }\end{array}$ \\
\hline Mourtzis et al. & $\begin{array}{l}\text { Tracking is marker-based only and easier to } \\
\text { implement }\end{array}$ & $\begin{array}{l}\text { Cannot replicate occlusion } \\
\text { Requires a bulky setup (laptop and mobile device) to } \\
\text { host the AR application } \\
\text { Requires interaction from end user for marker setup and } \\
\text { maintenance }\end{array}$ \\
\hline De Pace et al. & $\begin{array}{l}\text { Tracking is marker-based only and easier to } \\
\text { implement }\end{array}$ & $\begin{array}{l}\text { Cannot replicate occlusion } \\
\text { Requires interaction from end user for marker setup and } \\
\text { maintenance }\end{array}$ \\
\hline
\end{tabular}

Table 5rom Table 5, most of the techniques employed to perform tracking are marker based and with one utilizing both marker and computer vision techniques to execute the AR application. For mobile robots, marker has the advantage of providing features for the application to track as the surface of mobile robots may be metallic or reflective thus reducing the number of features that can be tracked directly.

In addition to that, occlusion is also important as it provides a sense of realism and allows the user to comprehend more easily what they are seeing during maintenance task. Applications without occlusion may result in an incorrect perception of the location of the virtual object. Furthermore, occlusion is also necessary to reduce the number of virtual objects immediately displayed to the user, so the user is not overwhelmed by the amount of information coming from the AR application. However, occlusion is generally more computationally expensive as it requires additional processing of spatial information that comes from mapping procedures.

\subsection{CONCLUSION}

Most of the proposed system reviewed in this paper uses marker-based approach to track objects for augmentation. This is likely due to the ease of implementation when compared to other more robust methods that uses localization techniques to identify the spatial location to place the augmented object. Additionally, marker-based approach is also typically less computationally expensive when used standalone. In addition to that, there are not many researches that implements the usage of $A R$ for the maintenance of robot especially in an industrial 
environment where different considerations are required such as frequent maintenance of markers which may be necessary in a harsh industrial environment. Future literature works can be focused on the application of markerless techniques such as 2D feature tracking or 3D object recognition for maintenance applications for robots as these techniques are already available in literature but applied in other fields such as aerospace maintenance.

\section{Acknowledgement}

This research work is supported by Universiti Teknologi Malaysia Research Grant [01M85, 4B402], Collaborative Research in Engineering, Science, and Technology (CREST) (https://crest.my/) R\&D grant [T20C2-18], and our industry partner DF Automation and Robotics Sdn. Bhd. (https://www.dfautomation.com).

\section{References}

[1] Amin, D. and S. Govilkar, Feb. 2015. Comparative Study of Augmented Reality Sak's. Int. J. Comput. Sci. Appl. 5(1): 11-26.

DOI: https://doi.org/10.5121/ijcsa.2015.5102.

[2] Mekni, M. and A. Lemieux. 2014. Augmented Reality: Applications, Challenges and Future Trends. Applied Computational Science - Proceedings of the 13th International Conference on Applied Computer and Applied Computational Science (ACACOS '14). 205214.

[3] Schmalstieg, D. and T. Höllerer. 2016. Augmented Reality-Principles and Practice. United States: AddisonWesley Professional.

[4] Palmarini, R., J. A. Erkoyuncu, R. Roy, and H. Torabmostaedi, Feb. 2018. A Systematic Review of Augmented Reality Applications in Maintenance. Robot. Comput. Integr. Manuf. 49: 215-228.

DOI: https://doi.org/10.1016/j.rcim.2017.06.002.

[5] Rongting, Z., S. Yiran, H. Tongliang, and F. Asmi, 2016. Applying Augmented Reality Technology to ELearning: Science Educational AR Products as an Example. 2016 IEEE 13th International Conference on eBusiness Engineering (ICEBE). 129-133.

DOI: https://doi.org/10.1109/ICEBE.2016.030.

[6] Detmer, F. J., J. Hettig, D. Schindele, M. Schostak, and C. Hansen. 2017. Virtual and Augmented Reality Systems for Renal Interventions: A Systematic Review. IEEE Rev. Biomed. Eng. 10: 78-94.

DOI: https://doi.org/10.1109/RBME.2017.2749527

[7] Dalim, C. S. C., T. Piumsomboon, A. Dey, M. Billinghurst, and S. Sunar. 2017. TeachAR: An Interactive Augmented Reality Tool for Teaching Basic English to Non-native Children. Adjunct Proceedings of the 2016 IEEE International Symposium on Mixed and Augmented Reality, ISMAR-Adjunct 2016. 344-345. DOI: https://doi.org/10.1109/ISMAR-Adjunct.2016.0113.

[8] Mokhtar, M. K., F. Mohamed, M. S. Sunar, M. A. M. Arshad, and M. K. Mohd Sidik. 2019. Development of Mobile-based Augmented Reality Colouring for Preschool Learning. 2018 IEEE Conference on eLearning, e-Management and e-Services, IC 3e 2018.
11-16.

DOI: https://doi.org/10.1109/IC3e.2018.8632639.

[9] Alrashed, M., Y. Yadekar, J. A. Erkoyuncu, and Y. Zhao, Jan. 2016. Examination of Robotic Aerospace Engines Maintenance Supported by Augmented Reality through Cloud Manufacturing. Proc. Int. Conf. Artif. Life Robot. 21: 445-449. DOI: https://doi.org/10.5954/ICAROB.2016.GS3-1.

[10] Luxenburger, A., J. Mohr, T. Spieldenner, D. Merkel, F. Espinosa, T. Schwartz, F. Reinicke, J. Ahlers, and M. Stoyke. 2019. Augmented Reality for Human-robot Cooperation in Aircraft Assembly. 2019 IEEE International Conference on Artificial Intelligence and Virtual Reality (AIVR). 263-2633. DOI: https://doi.org/10.1109/AIVR46125.2019.00061.

[11] Flatt, H., N. Koch, A. Günter, C. Röcker, and J. Jasperneite. 2015. A Context-aware Assistance System for Maintenance Applications in Smart Factories based on Augmented Reality and Indoor Localization. DOI: https://doi.org/10.1109/ETFA.2015.7301586.

[12] Brizzi, F., L. Peppoloni, A. Graziano, E. D. Stefano, C. A. Avizzano, and E. Ruffaldi. 2018. Effects of Augmented Reality on the Performance of Teleoperated Industrial Assembly Tasks in a Robotic Embodiment. IEEE Trans. Human-Machine Syst. 48(2): 197-206, DOI: https://doi.org/10.1109/THMS.2017.2782490.

[13] Sreeram, S., K. K. Nisha, and R. Jayakrishnan. 2018. Virtual Design Review and Planning Using Augmented Reality and Drones. 2018 Second International Conference on Intelligent Computing and Control Systems (ICICCS). 915-918, DOI: https://doi.org/10.1109/ICCONS.2018.8662919.

[14] Zaldívar-Colado, U., S. Garbaya, P. Tamayo-Serrano, X. Zaldívar-Colado, and P. Blazevic. 2017. A Mixed Reality for Virtual Assembly. 2017 26th IEEE International Symposium on Robot and Human Interactive Communication (RO-MAN). 739-744. DOI: https://doi.org/10.1109/ROMAN.2017.8172385.

[15] Fernández del Amo, I., J. A. Erkoyuncu, R. Roy, R. Palmarini, and D. Onoufriou, Dec. 2018. A Systematic Review of Augmented Reality Content-related Techniques for Knowledge Transfer in Maintenance Applications. Comput. Ind. 103: 47-71.

DOI: https://doi.org/10.1016/j.compind.2018.08.007.

[16] Coleta, G. F. Dela, A. Cardoso, E. A. L. Júnior, and G. F. M. de Lima. 2019. Telecommunications Field Operations Supported by Augmented Reality - A Systematic Review. 201921 st Symposium on Virtual and Augmented Reality (SVR). 77-83. DOI: https://doi.org/10.1109/SVR.2019.00028.

[17] Fraga-Lamas, P., T. M. FernáNdez-CaraméS, Ó. BlancoNovoa, and M. A. Vilar-Montesinos. 2018. A Review on Industrial Augmented Reality Systems for the Industry 4.0 Shipyard. IEEE Access. 6: 13358-13375. DOI: https://doi.org/10.1109/ACCESS.2018.2808326.

[18] Andersson, N., A. Argyrou, F. Nägele, F. Ubis, U. E. Campos, M. O. de Zarate, and R. Wilterdink. 2016. AREnhanced Human-Robot-Interaction - Methodologies, Algorithms, Tools. Procedia CIRP. 44: 193-198. DOI: https://doi.org/10.1016/j.procir.2016.03.022.

[19] Booth, A., D. Papaioannou, and A. Sutton. 2016. Systematic Approaches to a Successful Literature Review. SAGE Publications Ltd.

[20] Aschenbrenner, D., M. Rojkov, F. Leutert, J. Verlinden, S. Lukosch, M. E. Latoschik, and K. Schilling. 2018. Comparing Different Augmented Reality Support Applications for Cooperative Repair of an Industrial Robot. 2018 IEEE International Symposium on Mixed and Augmented Reality Adjunct (ISMAR-Adjunct). 69- 
74.

DOI:

https://doi.org/10.1 109/ISMAR-

Adjunct.2018.00036.

[21] Avalle, G., F. De Pace, C. Fornaro, F. Manuri, and A. Sanna. 2019. An Augmented Reality System to Support Fault Visualization in Industrial Robotic Tasks. IEEE Access. 7: 132343-132359, DOI: https://doi.org/10.1109/ACCESS.2019.2940887.

[22] Hietanen, A., R. Pieters, M. Lanz, J. Latokartano, and J.K. Kämäräinen. 2020. AR-based Interaction for Humanrobot Collaborative Manufacturing. Robot. Comput. Integr. Manuf. 63: 101891.

DOI:https://doi.org/https://doi.org/10.1016/j.rcim.2019. 101891.

[23] Michalos, G., N. Kousi, P. Karagiannis, C. Gkournelos, K. Dimoulas, S. Koukas, K. Mparis, A. Papavasileiou, and S. Makris. 2018. Seamless Human Robot Collaborative Assembly - An Automotive Case Study. Mechatronics. 55: 194-211.

DOI:https://doi.org/https://doi.org/10.1016/j.mechatro nics.2018.08.006.

[24] Michalos, G., P. Karagiannis, S. Makris, O. Tokcalar, and G. Chryssolouris. 2016. Augmented Reality (AR) Applications for Supporting Human-robot Interactive Cooperation. Research and Innovation in Manufacturing: Key Enabling Technologies for the Factories of the Future - Proceedings of the 48th CIRP Conference on Manufacturing Systems. 41: 370-375. DOI: https://doi.org/10.1016/j.procir.2015.12.005.

[25] Makris, S., P. Karagiannis, S. Koukas, and A.-S. Matthaiakis. 2016. Augmented Reality System for Operator Support in Human-robot Collaborative Assembly. CIRP Ann. 65(1): 61-64. DOI:https://doi.org/https://doi.org/10.1016/j.cirp.2016. 04.038.

[26] Kousi, N., C. Stoubos, C. Gkournelos, G. Michalos, and S. Makris. 2019. Enabling Human Robot Interaction in Flexible Robotic Assembly Lines: An Augmented Reality Based Software Suite. Procedia CIRP. 81: 1429-1434. DOI:https://doi.org/https://doi.org/10.1016/j.procir.201 9.04.328.

[27] Guhl, J., J. Huegle, and J. Krueger. 2018. Enabling Human-Robot-Interaction via Virtual and Augmented Reality in Distributed Control Systems. 7th CIRP Conference on Assembly Technologies and Systems (CATS 2018). 76: 167-170. DOI: https://doi.org/10.1016/j.procir.2018.01.029.

[28] Guhl, J., S. Tung, and J. Kruger. 2017. Concept and
Architecture for Programming Industrial Robots Using Augmented Reality with Mobile Devices Like Microsoft HoloLens. 2017 22nd IEEE International Conference on Emerging Technologies and Factory Automation (ETFA). 1-4. DOI: https://doi.org/10.1109/ETFA.2017.8247749.

[29] Zou, W., M. Andulkar, and U. Berger. 2018. Development of Robot Programming System through the use of Augmented Reality for Assembly Tasks. ISR 2018; 50th International Symposium on Robotics. 1-7.

[30] Linnerud, A. S., R. Sandøy, and L. E. Wetterwald. 2019. CAD-based System for Programming of Robotic Assembly Processes with Human-in-the-Loop. 2019 IEEE 28th International Symposium on Industrial Electronics (ISIE). 2303-2308.

DOI: https://doi.org/10.1109/ISIE.2019.8781385.

[31] Costa, C. M., G. Veiga, A. Sousa, L. Rocha, A. A. Sousa, R. Rodrigues, and U. Thomas. 2019. Modeling of Video Projectors in OpenGL for Implementing a Spatial Augmented Reality Teaching System for Assembly Operations. 2019 IEEE International Conference on Autonomous Robot Systems and Competitions (ICARSC). 1-8. DOI: https://doi.org/10.1109/ICARSC.2019.8733617.

[32] Blankemeyer, S., R. Wiemann, L. Posniak, C. Pregizer, and A. Raatz. 2018. Intuitive Robot Programming Using Augmented Reality. Procedia CIRP. 76: 155-160. DOI: https://doi.org/10.1016/j.procir.2018.02.028.

[33] Mourtzis, D., V. Zogopoulos, and E. Vlachou. 2017. Augmented Reality Application to Support Remote Maintenance as a Service in the Robotics Industry. Procedia CIRP. 63: 46-51. DOI: https://doi.org/10.1016/j.procir.2017.03.154.

[34] De Pace, F., F. Manuri, A. Sanna, and D. Zappia, Mar. 2019. A Comparison Between Two Different Approaches for a Collaborative Mixed-Virtual Environment in Industrial Maintenance. Front. Robot. Al. 6. DOI: https://doi.org/10.3389/frobt.2019.00018.

[35] Alves, J., B. Marques, M. Oliveira, T. Araújo, P. Dias, and B. S. Santos. 2019. Comparing Spatial and Mobile Augmented Reality for Guiding Assembling Procedures with Task Validation. 2019 IEEE International Conference on Autonomous Robot Systems and Competitions (ICARSC). 1-6.

DOI: https://doi.org/10.1109/ICARSC.2019.8733642. 